\title{
Public Archaeology in Greece: A Review of the Current State of the Field
}

\author{
Anastasia Sakellariadi \\ UCL Institute of Archaeology
}

\begin{abstract}
As far as archaeology deals with the past in the present, it is already a public endeavour; especially so in southern Europe, where contemporary identities are drawn from ancient cultures, such as the Greek and Roman. In Greece, the political role of the discipline marked antiquities as goods of the people and archaeology as a highly popular discourse. This led to the creation of a state mechanism to manage antiquities for the benefit, but ironically at the exclusion, of the people, in an authoritative top-down approach. In defiance, various actors participate in the public discourse about the past, cultural heritage and its roles today.

This paper will review the state of the field by bringing together research in public archaeology in Greece but also non-academic initiatives, such as NGOs and citizen movements. It is argued that public engagement, primarily through museum exhibitions the most formal and controlled interface between archaeology and non-archaeologists and cultural events in archaeological sites, is the primary aspect of public archaeology. While public archaeological discourse is overabundant and expansive though, critical research and analysis are lagging and conventional narratives remain broadly unchallenged.
\end{abstract}

Keywords: Public Archaeology, Greece, Museums, Heritage Management

\section{Introduction}

In Greece, antiquities and archaeology played an important role in the pursuit of independence from the Ottoman Empire and the establishment of the new nation-state. The first archaeological law (About scientific and technological collections, about the discovery and conservation of antiquities and their uses, 10/22 May 1834 in Petrakos 1982: 123-41), one of the earliest ones in Europe, explicitly stated that 'all antiquities inside Greece, because they are the works of the ancestors of the Greek people, are regarded as the national possession of the Greeks in general' (article 61). Thus, archaeology in Greece has been a public good and endeavour and has played a central social and political role since its foundation. 
The term 'public archaeology' has been variedly defined over time (Matsuda \& Okamura 2011: 4; Moshenska 2017: 3). Schadla-Hall's definition (1999: 147) as 'any area of archaeological activity that interacts or has the potential to interact with the public' remains the broadest and thus most fitting to the case of Greece because of the high national stake and interest of the past and of archaeology there. This paper uses Matsuda and Okamura's (2011: 5-7) four approaches to public archaeology perceived in a nonmutually exclusive continuum: educational, public relations, multivocal and critical. Overall, I advocate for an inclusive, dynamic and critical public archaeology, beyond the hybridity of a discipline and a practice, that concerns not only all archaeologists (Grima 2016) but societies at large. Inclusive and self-reflective archaeologies benefit societies and public archaeology research has already contributed towards that end.

This paper investigates current approaches to public archaeology in Greece through a review of the legal framework and of examples of educational, public relations, multivocal and critical public archaeologies. I argue that public archaeology activities have increased exponentially in the last forty years. The educational and public relations models dominate as they best accommodate and perpetuate state power and control over heritage management and, more importantly, meaning-making of the past and heritage. Although there are increasingly more instances of multivocal and critical approaches, these have challenged exclusive state control and authority over the past, rather than conventional narratives.

\section{Archaeology as the business of the State}

Classical antiquity's symbolic value and the entanglement of archaeology with the nationbuilding project have been discussed before (Hamilakis 2007 for more references). Here I will briefly address the current legal framework with respect to the role of archaeology in society. The Constitution first referred to the protection of the natural and cultural environment in 1975 (Skoures \& Trova 2003: 9). In 2001, this article was rephrased:

"The protection of the natural and cultural environment constitutes an obligation of the state and everyone's right. For its safeguarding, the state is obliged to take preventive and repressive measures in the frame of the principle of sustainability." (article 24, par. 1, The Constitution of Greece 2010: 38).

The right to protection as an individual right has supported in court citizens who challenge interventions in the environment (Voudouri 2003: 137, n. 22). Legal experts agree that constitutional protection of the environment extends not only to measures for protection from destruction but also to ensuring its enjoyment by as many people as possible and its enhancement as an element that enriches and improves quality of life (article 2, par. 1: On the State's Obligation to Respect and Protect Human Value, and article 5, par. 1: On the Right for Free Personality Development and Participation in the Social, Economic and Political Life, Voudouri 2003: 134).

The current law (Law no. 3028/2002, On the Protection of Antiquities and Cultural Heritage in General) aimed to enlist as much citizen cooperation in protection as possible through a system of rewards and compensations. The law grants protection through automatic state ownership of movable (art. 21) and immovable monuments (art. 7) dated up to 1453 and 
to later monuments under conditions. It describes in detail what constitutes a monument and conditions under which possession of one is allowed. Three out of seven aspects of protection refer to its social dimension: facilitation of access to and communication of the public with heritage (article 3, paragraph 5), enhancement and integration into contemporary social life (article 3, paragraph 6) and education, aesthetic enjoyment and public awareness (article 3, paragraph 7). Protection is exclusively implemented by central and regional services (Ephorates) of the Ministry of Culture, collectively referred to as the Archaeological Service (from now on AS).

Further measures on access to and use of monuments set the regulatory framework for this social dimension of protection. The law endorses visitation as the common means of peoples' use of monuments, under conditions, and on the basis of archaeological legislation going back to the nineteenth century (Gogos 2004: 306, 317). The use of a monument to host an event can be granted by ministerial decision again under conditions and after the relevant Council's recommendation. One of the conditions is the compatibility of the event with the character of the monument or site (article 46, par. 1). Events need to concur with the original use of monuments and be of 'appropriate quality(Papapetropoulos 2006: 200), without specifications as to what 'appropriate quality' means. Therefore, approval depends greatly on discrete power and prediction of the extent of wear of the monument (Gogos 2004: 309-10).

The belief that it is part of the state's duty of protection to ensure the 'ethical' use of antiquities, control meaning-making and safeguard their 'sacredness' from any insult or vilification is widespread and results in a patronising attitude that occasionally borders on censorship, in breach of constitutionally protected human rights (Voudouri 2003: 236238). General Secretaries of the Ministry have occasionally reacted to 'international provocations' ranging from the use of an image of the Parthenon by Coca Cola to covers of the German magazine Focus (see Hamilakis 2007: 5-9; Thermou 2010a).

\section{Archaeology as everybody's business}

In spite of the state's exclusive control, the past, antiquities and archaeology constitute a highly engaging topic of public interest. Primarily due to the strong entanglement of archaeology with national identity in Greece, expressions of valorisation of the past and of archaeology are ubiquitous in the public sphere. The public understanding of the past is formed in school, through books and other media, and living close to archaeological sites and expressed interest in archaeology is high (Sakellariadi 2011: 269 - 270, 203 -205; Fig. 1). In this sense, archaeology and its interface with the public sphere differ greatly between the US or the UK, for example, and Greece. A comparison between general population and local communities' survey replies to the question "what do you think of when you hear the word 'archaeology" demonstrates that participants in the former cases are more likely to give accurate or reasonable definitions of the meaning of the word while in the latter ones participants are more likely to give emotive replies and replies mediated through personal experience (Sakellariadi 2011: 200-202 for more references). 


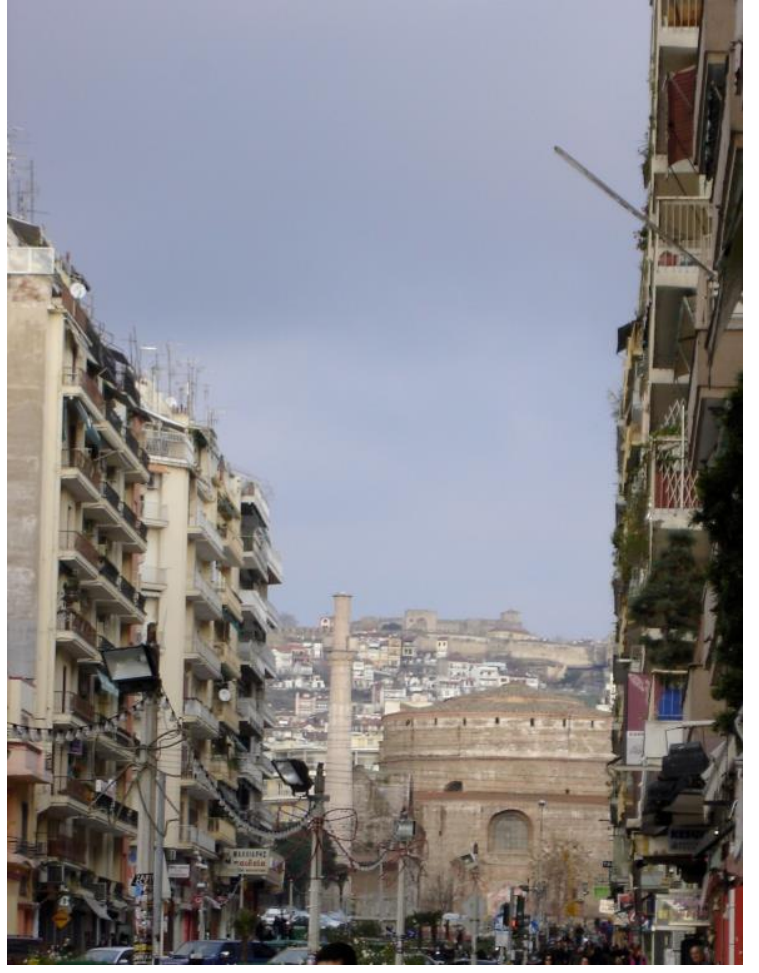

Figure 1. Monuments and sites often dominate city centers. The Arch of Galerius, the Rotunda and the Byzantine city walls in Thessaloniki
The terms 'public' and 'public archaeology'

Public archaeology has been translated in

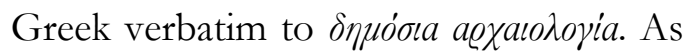
in other languages (see Matsuda and Okamura 2011: 3-4), the term is ambiguous. Similarly to the term 'public', the word $\delta$ inos encompasses both the officialdom and the populace. However, the term most commonly used to refer to the latter is to rowvo', 'audience' (Dictionary of Standard Modern Greek, тo xoเvó), a collective noun that masks variation, assumes passivity and absolves of the responsibility to understand who the public is. The term roıvo prescribes a very specific and absolutely controlled role for people under conditions that leave no room for initiatives or alternatives; a use particularly fitting for educational and public relations models of public archaeology. Similar concerns have been raised in museum studies (Hooper-Greenhill 1999: 67-72). One of the first mentions of the term in Greek bibliography was at the conference "The Present and the Future of our Monuments. Cultural Heritage and $3^{\text {rd }}$ Community Support Framework: The Offering of the Archaeological Service to Civil Society", organised by the trade union of state-employed archaeologists at the Ministry of

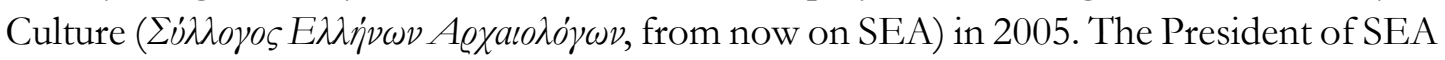
stated that Greek archaeology needs to transition 'from [being] state to [being] public...' (Athanasoulis 2007: 28). Athanasoulis, a proponent of a more socially integrated state archaeology, often identifies public archaeology with state archaeology (Athanasoulis 2021). However, this use of the term limits public archaeology to the exclusive realm of the state. While state archaeology indeed is part of public archaeology and, admittedly, it is McGimsey's (1972) original meaning of the term, public archaeology should under no circumstances be exclusively identified with and limited to state archaeology.

In 2012, Kaleidoscope Publications launched a book series titled Public Archaeology. In its first volume, Galanidou, a Professor in Prehistoric Archaeology and organiser of the first conference on public archaeology in Greece (Anuóoıa Aexaıodoyia, $12^{\text {th }}-14^{\text {th }}$ May 2017, University of Crete, Rethymnon) defined public archaeology:

"Public archaeology is a sum of theories, methods, hypotheses and practices that guide, inspire and motivate the entire spectrum of archaeological process and action: from discovery, conservation and interpretation up to the presentation of archaeological testimonies, as well as of the archaeological sites and landscapes that surround them. The biggest motivation is the transfer of the scientific and experiential [accomplishments] of archaeological science/discipline to the public. In a reversed course, the reception of the [conclusions] of the archaeological discipline/science from the public space and their interaction also fall within the scope of Public Archaeology. Their 
subjects [are] archaeologists and everyone who is involved in the process of acquisition, study, interpretation, narration, protection and enhancement of archaeological remains. Its subject also [is] the public that embraces, adopts, internalises, reproduces or rejects archaeological activity and narrative". (Galanidou 2012: 9; my translation).

In this definition, the focal and starting point of public archaeology is the discipline of archaeology and its practices. Knowledge transfer is its drive. The public sphere ( $\chi \dot{\omega} \varrho \circ$ ) receives and interacts with archaeology and the public (rovvo), mentioned last, reacts to archaeological activity and narratives. This is a very archaeology-centric understanding of public archaeology that substantiates the concerns raised about the use of the term rovvo (see above).

Courses in museology were the first ones to be introduced in archaeological undergraduate curricula. Postgraduate courses followed, later combined with cultural management (e.g. at the Aristotle University of Thessaloniki). Eventually two departments were founded at the Universities of the Peloponnese (History, Archaeology and Cultural Resource Management) and of Patras (Cultural Heritage Management and New Technologies, now re-founded as History and Archaeology). Public archaeology as a subject is being taught at the University of Crete (Galanidou pers. com.) and the University of Patras. The course is also included in the new programme of studies at the Archaeology Department of the Aristotle University of Thessaloniki, which has not been implemented yet.

\section{Educational model}

The educational role of archaeology has always been important in Greece because of its association with the national identity. It is no surprise then that the educational model of public archaeology dominates in Greece. Archaeological museums have been considered the main vehicle for the fulfilment of archaeology's educational role, secondary only to their main role, of protection and storage (Gazi 1993). Legislation envisaged this role as 'the teaching and study of archaeology, the general diffusion of archaeological knowledge and the generation of love for the fine arts' (Royal Decree, 25/11/1885). Throughout the twentieth century distinguished archaeologists supported museums' educational mission (e.g. Karouzos mentioned in Petrakos 1995: 348-51; Bakalakis mentioned in Dassiou 2005: 24; Theocharis 1984: 80-85). This expectation is also reflected on values people place on archaeology where educational value comes second only to the historic one (Sakellariadi 2011: 277 - 278).

There are 203 archaeological museums in the country today (Archaeological Museums 2021). Many new museums opened, and many old ones were renovated with the opportunity of the Athens Olympics (2004) and funding from the Second Community Support Framework. Museum exhibitions remain the primary means of official public engagement with archaeology. Effectively, the social dimension of protection under the current law begins and ends with a visit to a museum or an archaeological site. Several conditions though cast doubt over the effect the increase in museum numbers and their aesthetic and technological renovation has had on the quality of visitor engagement. Museums and archaeological sites constitute highly regulated spaces, where formal approaches enjoy full and uncontested authority over the visitor. The alienating effect of 
glass cases combined with lack of visitor-friendly interpretation and the dominance of jargon-laden information (Gazi 2006) do not render archaeological museums in Greece a desirable destination for Greeks (Thermou 2010). School trips and foreign tourists make up the vast majority of museum visitors.

Additionally, museum and exhibition evaluations are not common in Greece (see Bounia \& Mouliou 2009 for a few exceptions). Internationally, the need to democratise intellectual and physical access to culture and the change from state-funded to self-sufficient finances in the museum sector, necessitated the re-evaluation of the role and value of museums. Evaluations have been employed in order to establish that museum exhibitions are not only relevant to communities' interests but also accessible, intellectually and physically, and successful in achieving their goals (Moussouri 1999). Neither condition has occurred in Greece in order to necessitate the evaluation of museums' and exhibitions' roles. Social relevance is taken for granted thanks to archaeology's link with national identity and thus, is not a priority.

Archaeological museums have also been offering educational programmes since the early 1980s (Sakali 2017: 271, earlier in private museums). At first traditional archaeologists faced them with suspicion, that '[they] are trying to render museums from spaces of academic study and admiration of ancient art to playgrounds' (Sakali \& 'Tsitouri 2017: 88). European funding and commemorative days helped museum education develop. After the initial period Sakali calls 'heroic' and 'ambitious', a period of innovation followed in the development of museum education programmes, where alternative and critical discourses were promoted about the past. The decade 2005-2015 saw an expansion to groups such as prison inmates, blind and partially blind people, people with disabilities but also their devaluation from the state. The abolition of Departments of Educational Programmes in 2014 (Presidential Decree 104/2014) meant that very few museums and sites regularly host educational programmes (Sakali 2017: 271-2). Finally, an evaluation of printed material used in museum education programmes showed them to recycle 'stereotypical representations of the national self (Sakali 2015: 30). Museum education is not a priority.

Of much more local impact, nonetheless important, have been educational initiatives of university and foreign school excavations since the early 1990s (e.g. in Petras, Wedde 1995, in Dispilio et al.: 2010). At approximately the same time, the institution of Environmental Education Centres was founded in Greece and gradually expanded to 53 centres all over the country. The cultural environment falls in the remit of activities of these Centres and educational programmes focusing on near-by antiquities are often included in their programming (EEC 2008; Sakellariadi 2011). Their importance should not be undermined although it has not been assessed yet.

Publishing activities that would fall in the educational approach are also worth mentioning although assessing their reach and effect is not possible without further data. The magazine Archaeologia \& Technes (Archaeology \& Arts) was published from 1981 to 2010 with the aim to make archaeology accessible to the general public. In 2015, it was relaunched as an online magazine in addition to its printed edition. In 2016, Themata Archaeologias (Issues in Archaeology) was founded also aiming at the 'dissemination and appropriation by the general public of the way of thinking and achievements of Archaeology and History of Art'. I will not refer here to academic publications and 
conferences, such as the annual meetings presenting archaeological work by region, as their primary aim is scholarly communication rather than public education.

\section{Public relations}

\section{Commemorative days and other cultural events}

Cultural events organised in archaeological museums and sites have proliferated in recent years. Such events are international days (e.g. ICOM's International Museum Day, the Council of Europe European Heritage Days, ICOMOS's International Monuments Day, International Museum Night, the European Confederation's of Conservator-Restorers' Organisations European Day of Conservation of Cultural Heritage) and cultural events hosted in museums and sites, especially ancient theatres (Fig. 2), such as summer-long festivals, music recitals, photographic exhibitions, August full moon night concerts etc. Their aim is to integrate antiquities and archaeology with social life, to justify the need for their preservation and contribution, ensuring their license to be conserved and demonstrating their impact in real life. They thus play an instrumental role in cultural policy (Matsuda 2016).

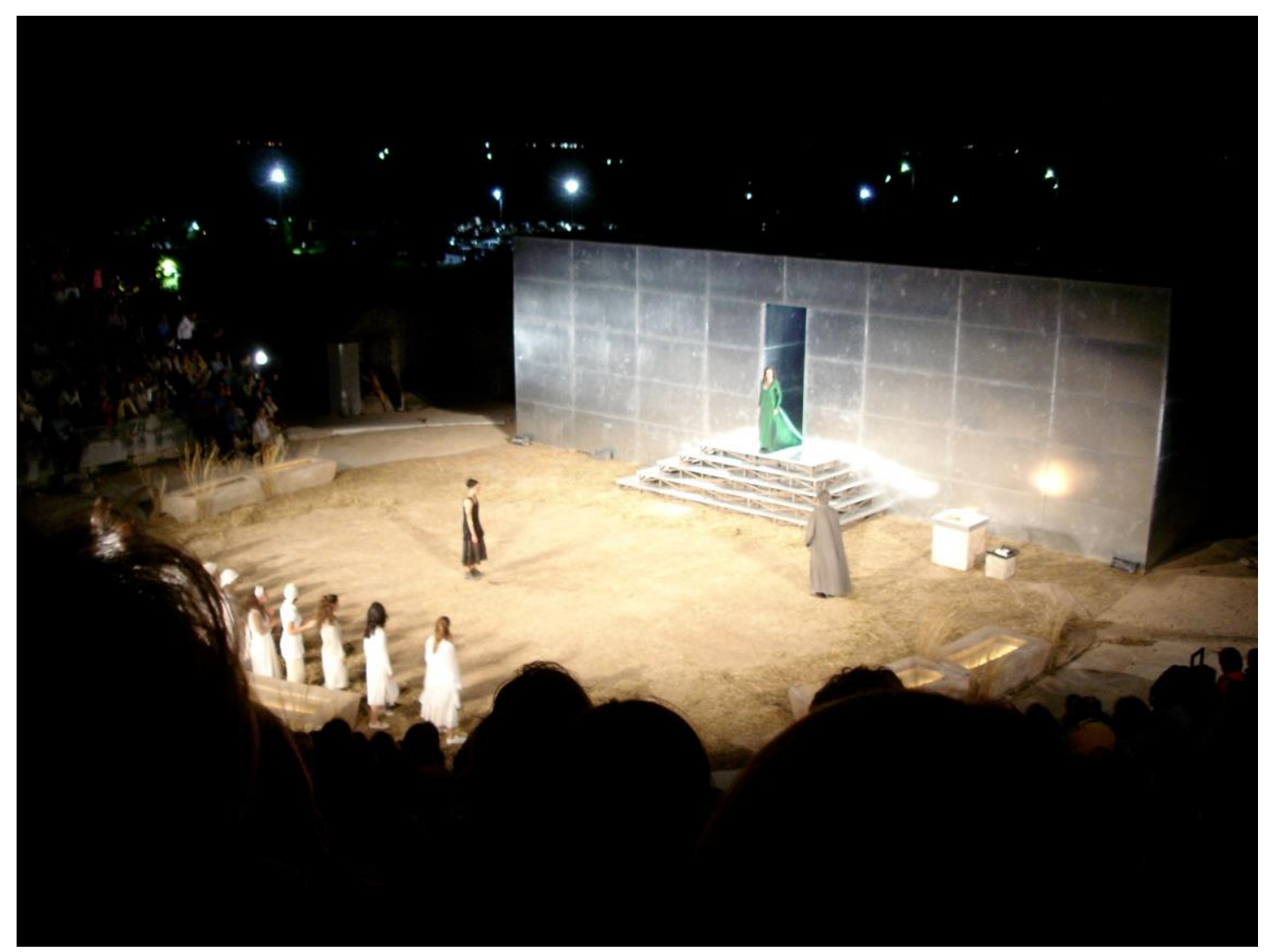

Figure 2. Ancient drama festivals are hosted in well-preserved ancient theatres in summer. Sophocles's Electra directed by Peter Stein at the Philippi Festival, 2007.

\section{Trade union events}

In 2012, SEA organised an international campaign titled Support Greek. Cultural Heritage Against IMF Cuts in order to protest the cuts in public spending agreed in the memoranda Greek governments signed with the Troika to tackle the economic crisis (SEA 2012a). 
This activity resulted in the establishment of the Action Day for the Promotion of the Multifaceted Work of the Archaeological Service - also mentioned as Archaeological Service Day (SEA 2013) or Day of the Archaeologist (SEA 2017). The public relations approach is explicitly stated in the title and every announcement regarding this event. The AS is emphasised as the exclusive actor in protection and conservation. In spite of the efforts to address issues other experts employed by the AS face, the AS and archaeologists remain its focus. The original scheduling of this day in October would make someone think that it was conceived in imitation of the International Archaeology Day of the American Institute of Archaeology. However, once one reads the press releases ${ }^{1}$ it becomes clear that the focus is on the work of the AS and its justification in social, political and economic terms (SEA $2012 \mathrm{~b}$ ) and not the value of protection and conservation in general. The week-long celebration included 30 - 60 events, primarily educational programmes, but also guided tours to museums and sites, film screenings, photographic exhibitions, lectures, a race and an experimental archaeology event. The vast majority of events ran during the week and during working hours with considerably fewer ones scheduled for the weekends or evenings, as necessitated by the bureaucracy of state services; highlighting the contradiction of an event aiming to be participant-friendly but organised within the limitations of a state service's operations and at the expense of public resources.

In the same vein, the Union of Contract Archaeologists (SEKA 2021) announced its First Scientific Meeting of Contract Archaeologists in an effort to 'highlight the scientific role of contract archaeologists' as part of 'a series of activities that will promote the work of its members'.

\section{Social media}

More recently, the Ministry of Culture and a few Ephorates and archaeological museums entered the world of social media (more commonly, Facebook). For now, their limited online presence is exhausted in the promotion of press releases, exhibitions and other events rather than in building social networks and opening up channels of communication (Theochari et al.: 2015). The unfortunate setup as individual user profiles rather than as organisations' public pages, with the exception of two cases (out of ten, currently in total), demonstrates that no social media training or communication and networking strategy preceded this effort.

\section{Multivocal}

With time, more individuals and communities choose to publicly address their own pasts in Greece. Oral history emerged recently and spread widely through local groups and

\footnotetext{
1 “...dramatic developments in the public sector and the Ministry of Culture and Sports render the need to act and promote our goals more topical than ever...", “...to sensitise public opinion on issues related to the care and enhancement of cultural heritage...", “... a series of varied events that promote the important (excavation, anastylosis, museum, educational etc.) work undertaken by the Archaeological Service and its importance for the economy, the development, the enhancement of the identity and education of the local community...", “...to talk to visitors, friends of museums and local communities about the way we work etc.", "Colleagues, during critical times for the country and the Archaeological Service, the promotion of our work and the search for allies in society will be the most important weapon for the protection of monuments" (SEA 2012b).
} 
nation-wide initiatives, such as Istorima (2021). Eighteen groups are currently listed at the Oral History Groups webpage (2021). The also recent emergence of public history demonstrates that contemporary pasts are slowly making their way to the public sphere, beyond archaeology and antiquities. Finally, there is a proliferation of social media groups sharing resources and archival material online from the more recent past (e.g. Ottoman). NGOs, residential activism, but also individuals' relationship with the past and its remains fill an important gap in official AS narratives and challenge its exclusivity in the absence of a participatory and collaborative heritage management framework at a fast pace (cf. Sakellariadi 2008).

\section{Non-Governmental Organisations}

NGOs focused on culture have a relatively long history in Greece. The oldest one, the Hellenic Society for the Protection of the Environment and Cultural Heritage, was founded in 1972 in reaction to the Colonels' Junta extensive destruction of monuments and played a major role in the protection of the iconic neighbourhood of Plaka in Athens and of Delphi. The Society claims to have contributed to the formulation of article 24 of the Greek Constitution (Hellenic Society 2021, see above).

Diazoma was founded in 2008 by a former member of parliament and minister and quickly drew in many distinguished university archaeologists, artists and other public figures (Diazoma 2021). Its main remit is the preservation and integration in contemporary life of ancient theatres through funding of technical studies required for enhancement works in ancient theatres. Diazoma strives to demonstrate transparent management and funding structures by publicising the names of individual donors and donated sums, legal agreements and even committee meetings.

MOnuMENTA (2021) started off as an e-magazine in 2007 to promote awareness, protection, sustainable management and enhancement of the natural and architectural heritage in Greece and in Cyprus. Since then, MOnuMENTA has developed a series of important projects that fill in considerable gaps in the state's protection programme. MOnuMENTA has mobilised volunteers and school groups in documentation and research projects and even crowdsourced social media users to support its activities and activism (e.g. Recording and Promotion of $19^{\text {th }}$ and $20^{\text {th }}$ c. buildings in Athens, Buildings at Risk in Greece: Photograph-Record-Protect, Monuments at Risk etc.). MOnuMENTA currently leads a group of signatories demanding that the Ministry of Culture stops extensive renovation works at the Acropolis of Athens in the last few months (Acropolis SOS 2021; Dragouni et al.: 2021).

In 2014 an annual meeting called Archaeological Dialogues was established with the aim of fostering critical and self-reflective conversations about antiquities and archaeology in contemporary society. The meeting is open to all participants, types of events and issues. Five meetings have been organised to date covering a range of topics, such as archaeology today, borders, migrations, cities/urban environment (Archaeological Dialogues 2021). The Association of Heritage Management Consultants (ESDIAPOK 2021) was founded in 2014. Its aim is the sustainable protection of cultural heritage for the benefit of society as upheld in international best practices in strategic and participatory heritage management. ESDIAPOK has been organizing annual conferences, lectures, and other 
events. In 2020, ESDIAPOK launched the online open access academic journal Critical Studies in Cultural Heritage (CSCH 2021).

\section{Residential activism}

At the same time, residential activism rose to the forefront with prominent cases such as the Filopappou Hills and Akademia Platonos in Athens (Stefanopoulou 2019) and the Citizens' Movement of Thessaloniki for the Protection of Cultural Heritage (CMTPCH 2021). Although public protests against AS decisions are not new, the level of organisation and activism recently witnessed reveals a whole set of values and meanings heritage bears that are currently excluded by the AS (Stefanopoulou 2019). Social media have enabled and empowered such movements.

The case of SEA

SEA is the trade union of state employed archaeologists at the Ministry of Culture and its services. Its name implies the representation of all Greek archaeologists, but this is not the case. Furthermore, its activity extends well beyond labour law to issues of protection and conservation in a paradoxical way: SEA often protests the decisions that its members are called to implement as state employees while other times SEA employs Ministry of Culture resources as its own, blurring thus the lines between state service, public property and resources and trade unionism (see above, the Day of the Archaeologist). Nevertheless, SEA has established itself as a stakeholder in heritage management in Greece at the exclusion of other archaeologists, conservators and other heritage professionals.

\section{Private archaeologies}

Are individual relationships with archaeology part of public archaeology especially if these are expressed, e.g. through illicit excavation and collecting (Antoniadou 2009), blogging about one's experience of rescue excavation (Psychogios 2009) or the many ways antiquity is consumed in today's societies (Consuming Greek Antiquity 2021, Fig. 3)? While it is more difficult to identify and study individual interest and engagement with archaeology, we should not ignore them either. Public perception studies demonstrate that archaeology is valued highly in Greece (well over the European average, Kadja et al.: 2017: 10-11) and even more so among communities local to archaeological sites, where participants interested in archaeology are the majority (Sakellariadi 2011: 203-206). 


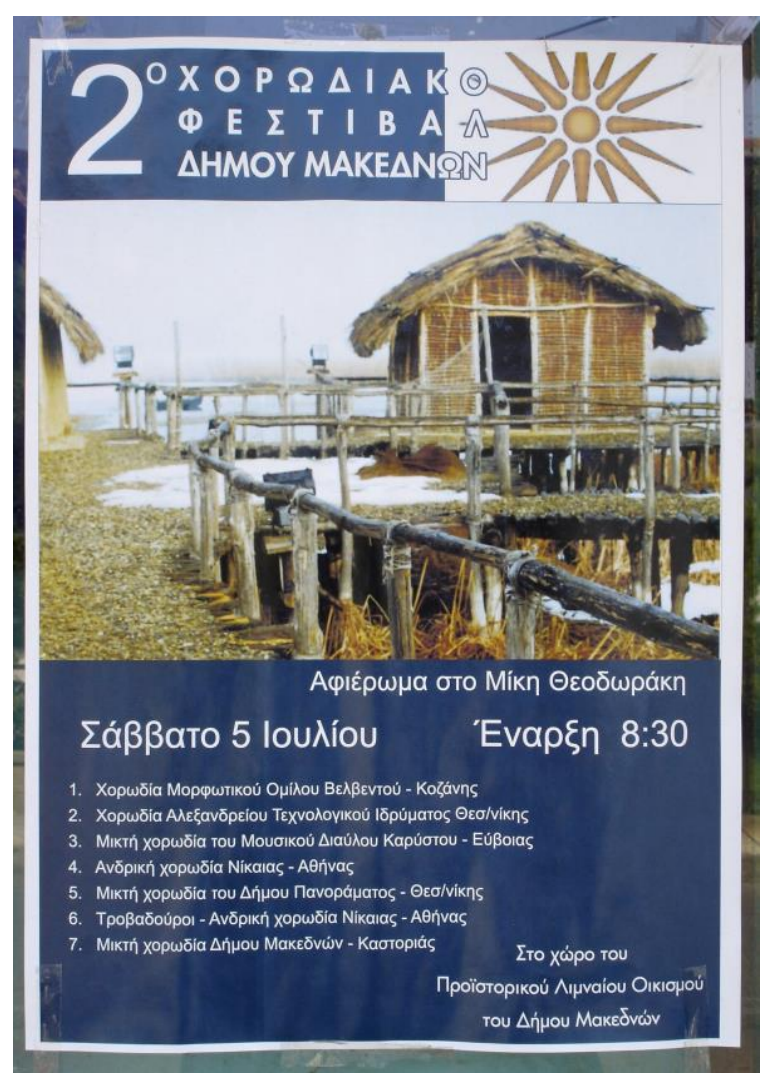

Figure 3. The poster for the promotion of the City's chorus festival in Dispilio in 2008 used an image of the prehistoric lake settlement reconstruction and the socalled Vergina star although the festival was dedicated to contemporary music. The festival took place at the reconstruction site.

\section{Critical}

The critical approach of public archaeology could be loosely identified with research in public archaeology. While it is true that the major impetus came primarily from the UK and the US, its seeds are found in the work of Greek scholars in Greece well before that.

\section{Public archaeology before public archaeology}

This is the case of George Ch. Chourmouziadis who introduced, embedded in his archaeological theory, a critical perspective on archaeology and its social role in Greece (Chourmouziadis 1980; 1990).

Intellectual, politician, believer in the potential of archaeology to improve people's lives, he had his own way of making archaeology relevant, tangible and accessible not only to his students, but also to the readers of his books and the listeners of his radio programmes (Chourmouziadis 1999).

He applied his views in the design of the prehistoric exhibition at the Archaeological Museum of Volos, where artifacts were displayed outside of glass cases, using common materials for the Neolithic period, such as wood and clay, and contextualised according to use rather than in typological or chronological sequences. As director of the university excavation of the lake settlement of Dispilio he tried to materialise his belief that '... an excavation is not a simple process of discovery of artifacts but an invitation to participate in the creation of another culture, the formation of a different human, the setting up of another, new and just society' (Chourmouziadis 2008; Chourmouziadis 2002; Kotsakis 2019).

\section{Public archaeology research}

Critical perspectives on archaeology and society in Greece (indicatively see, Gratziou 1985; Snodgrass 1987; Zoes 1990; Kotsakis 1998; Doumas 1997; Fotiadis 1993; 1995; 2001; Shanks 1995), politics of the past (Kotsakis 1991; Kalpaxis 1990; 1993), and local communities surveys (Kotsakis et al.: 1993) were being published throughout the 1980s and 1990s. Although conventional archaeological research remained the focus of these authors' work, they perceived the importance of critically contextualising their discipline and prioritised it highly enough to publish. Their contributions laid the foundations for further public archaeology work and research. 
In parallel, a wide array of studies from different fields contributed to a multi-disciplinary knowledge base for public archaeology: from anthropological research in historical consciousness formation (Sutton 1998), heritage management and values (Herzfeld 1991; Yalouri 2001; Caftantzoglou 2001), museum (Gazi 1993) and exhibitions' history (Mouliou 1997). Domestic museology had started developing very slowly in the 1980s mainly through conferences and more rapidly from the end of the 1990s and the 2000s onwards (Skaltsa 2014).

In 1996, Hamilakis and Yalouri published Antiquities as Symbolic Capital in Modern Greek Society, a cornerstone in the study of the role of antiquity and antiquities in contemporary Greece and launched a new era of dedicated research in public archaeology. Hamilakis has internationalised the case of Greece while advancing its theoretical implications. Soon after, general works (Kokkinidou 2005) and Ph.D theses were completed mainly at the Aristotle University of Thessaloniki and at the University of Crete on the politics of archaeology in early 20th c. (Sakka 2002), archaeology in the nineteenthcentury press (Sophronidou 2003), archaeology in elementary school books (Kasvikis 2004) and among elementary school students (Dassiou 2005). The new archaeological law (3028/2002) gave impetus to critical legal approaches to the new framework (Papapetropoulos 2006; Skoures \& Trova 2003; Trova 2004). In 2008, Dimitris Plantzos and Dimitris Damaskos organised the conference Singular Antiquity where an overview of research in the role of antiquity in modern Greece was presented (Plantzos \& Damaskos 2008; Sakellariadi 2007). Since then, Plantzos has also contributed with critical and theoretically informed work on contested meanings of antiquities and identities (e.g. Plantzos 2008; 2016). The history of archaeology in Greece is still covered primarily in conference proceedings in a range of approaches from celebratory to more critical ones (for an exception see Varouhakis 2015).

In the last 10 years, focus has been placed on heritage management (Alexopoulos \& Fouseki 2013; Lekakis \& Pantzou 2020) and local communities (Hamilakis \& Anagnostopoulos 2009; Kyriakidis \& Anagnostopoulos 2017; Sutton \& Stroulia 2010, Gratsia \& Lekakis 2010, Sakellariadi 2011; Stefanopoulou 2019; Dakouri-Hild 2017). The economic crisis in 2009 also incentivised a series of studies on the economic value of heritage and the effects of the crisis on heritage management (Academy of Athens 2006; Howery 2013; Plantzos 2018; Poulios \& Touloupa 2018). However, the field is vast and the opportunities for research remain largely unexplored.

\section{Discussion}

Antiquities in Greece are a public resource managed at the exclusion of the public. Although public archaeology has undoubtedly made great strides in all four approaches (educational, public relations, multivocal and critical), it is worth considering the qualitative characteristics of its practices. The number of educational programmes that recently renovated and refurbished archaeological museums offered was steadily increasing until the economic crisis and the structural reform of the Ministry of Culture services. Their assessment has demonstrated that overall educational programmes were reinforcing stereotypical approaches rather than elaborating on more recent understandings of the past. 
Public relations activities, alongside educational ones, are without doubt the most dominant forms of public archaeology in Greece because they accommodate the topdown heritage management mechanism that the country has employed for 200 years now in order to control heritage-meaning making. Hence, the nation-centric character of archaeology in Greece remains unaffected. Although, admittedly, the events that have been organised in archaeological museums and sites around the country with various opportunities in the last twenty years have created a more open and welcoming image for official heritage.

On the other hand, multivocal and critical approaches that are challenging the established character and role of archaeology are also developing. Recent decisions in heritage management in Greece have also contributed to this direction through the extent of protests they have stirred: the change of the legal status of five major archaeological museums, the renovation works on the Acropolis of Athens and the removal of the Byzantine crossroad excavated during the metro works in Thessaloniki. Multivocal and critical approaches are important in maintaining archaeology's relevance and in sustainable heritage management.

The seeds of what we could call today public archaeology have existed in Greece for a very long time. Antiquities and the means for their discovery, archaeology, have been linked with the nation-building project since its inception. Critique of the role archaeology ended up playing in society became more vocal from the 1980s onwards. George Chourmouziadis was an early advocate of public archaeology through his multifaceted activity in archaeology and beyond. The role of British and American scholarship is undoubtedly considerable although a niche of Greek scholars has developed a substantial body of knowledge on public archaeology in Greece. Teaching in undergraduate and postgraduate courses, regular conferences, and establishing open access publishing venues are necessary requirements for its further development.

\section{A note on the four approaches of public archaeology}

The theoretical framework proposed by Matsuda and Okamura (2011; based on previous work by Holtorf and Merriman) is a convenient way to organise this review. In the process, however, I came across several limitations. Their detailed elaboration exceeds the scope of this review. In brief, although conceived as categories with some overlap between them, the extent of potential overlap only becomes obvious when one tries to apply them. Any aspect of public archaeology is likely to have educational, public relations and critical aspects and to be multivocal at the same time. The theoretical scheme presumes and best serves archaeologists' own public archaeology activity: three categories based on intent (e.g. to educate) and one based on the position one is willing to accept in a wide array of views (e.g. multivocal). What does the category multivocal say about the intentions of residential activists other than that they are not officials?

In the more general conception of public archaeology in Schadla-Hall's definition, 'archaeology' should be perceived beyond the confines of the discipline as any discourse about the past engaging with material culture even if it comes from non-experts in order to capture the full extent of what public archaeology may be. This is particularly necessary in contexts where archaeology is a more widely appropriated discourse as is the case of Greece. This proposition also demonstrates that identifying the Mediterranean and 
Eastern Europe as peripheral in the development of public archaeology hinders our understanding of the particularities of these contexts that could instead allow us to make original contributions to the field and its theoretical background.

\section{Conclusion}

In the last forty years, there has undoubtedly been a great increase in the number of opportunities people have to engage with antiquities and archaeology in Greece. These range from scenario-based educational programs to other cultural events enjoyed with the backdrop of impressive monuments, to residential activism and online debates on the present and future state of archaeological heritage. Changes in the legal framework of major museums, the Byzantine crossroad revealed during construction of the Thessaloniki metro, and renovation work on the Athens Acropolis currently are all topics of major critical public debate in Greece.

Commonly in most other places in the world educational and public relations approaches dominate because they fit well in the top-down official system of heritage protection. Alongside these and often in direct antagonism with the AS, multivocal and critical approaches are constantly multiplying. The gradual introduction of courses in public archaeology and heritage management in university curricula and the establishment of relevant organizations and publication venues support these strands of public archaeology. All these constitute major steps toward the democratisation of heritage and its sustainable management as a socially embedded practice and discipline.

In the near future, we will witness the struggle between public challenges of official histories and top-down narratives that remain broadly unchallenged. This struggle guarantees that public archaeology will be a vibrant arena of debate in the years to come. While educating all archaeologists on the benefits of public archaeology is absolutely necessary for the advancement of the field (Grima 2016), a specialised field, trained in public archaeology research is a pre-requisite for the advancement of the knowledge base that will enable critical approaches in public archaeology. Hence, the Eastern Europe and the Mediterranean, and Greece in particular, are not peripheral to the development of public archaeology but present their own conditions and challenges and can contribute to public archaeology theory and research through their own paradigms.

\section{References}

Academy of Athens 2006. Cultural Heritage as a Development Factor for the Greek Economy (in Greek). Athens: Academy of Athens.

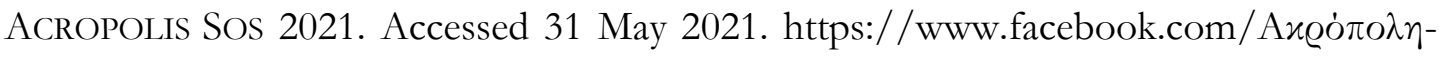
$\Sigma O \sum$-Acropolis-SOS-104797271721056/

Alexopoulos G. \& FouseKi K. (eds), 2013. Managing Archaeological Sites in Greece. Conservation and Management of Archaeological Sites 15(1).

Antoniadou I. 2009. Reflections on an Archaeological Ethnography of 'Looting' in Kozani, Greece. Public Archaeology 8 (2-3): 246-61. 
Archaeological Dialogues 2021. Accessed 31 May 2021. https://www.facebook.com/groups/807619712595568/about Archaeological Museums 2021. Accessed 31 May 2021. https://archaeologicalmuseums.gr/el

Athanasoulis D. 2021. Public Archaeology and Museums. Presentation at A Conversation About Greek Archaeological Museums. Master's Programme in Museum Studies. National and Kapodistrian University of Athens, 1st March 2021. Accessed 31

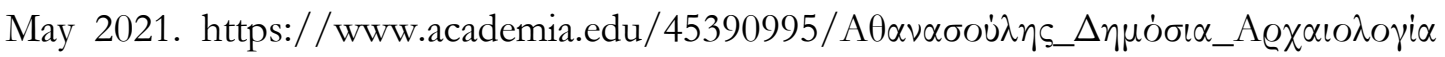
_and_Movocia

Athanasoulis D. 2007. Monuments Delivered to Citizens Using the Method of SelfSupervision, in: Association of Greek Archaeologists (ed.), The Present and the Future of our Monuments. Thessaloniki: Association of Greek Archaeologists: 26-9.

Bounia A. \& Mouliou M. (eds), 2009. Evaluation and Audience Research (in Greek). Tetradia Mouseiologias 6.

Caftantzoglou R. 2001. In the Shadow of the Sacred Rock (in Greek). Athens: Ellenika Grammata.

Chourmouziadis G. 2008. Transcription of a Talk Given at the Lakeside Festival. Dispilio, 23 August 2009.

Chourmouziadis G. (ed.), 2002. Dispilio 7,500 years later (in Greek). Thessaloniki: University Studio Press.

Chourmouziadis G. 1999. Words made of earth (in Greek). Skopelos: Nesides publications. Chourmouziadis G. 1990. Greek Archaeology Between the One-Way Road of the Past and the Labyrinth of the Future: A Brief but Pessimistic Critique (in Greek), in: LAZARIDIS D. (ed.) In the Memory of D. Lazaridis: City and Chora in Ancient Macedonia and Thrace. Proceedings of an Archaeological Conference, Kavala 9-11 May 1986. Athens: Ministry of Culture, École Française d'Athènes: 719-725.

Chourmouziadis G. 1980. The Archaeological Museum in Greece: School or Temple? (in Greek, abstract in English). Themata chorou ke tecnon/ design in Greece 11: 38-42.

CмтPCH 2021. Citizens' Movement for the Protection of Cultural Heritage. Accessed 31 May 2021. https://kinisipolitonthessalonikis.blogspot.com/

Constitution of Greece 2021. The Constitution of Greece. Accessed 31 May 2021. https://www.hellenicparliament.gr/Vouli-ton-Ellinon/To-Politevma/Syntagma/

Consuming Greek Antiquity 2021. Accessed 31 May 2021 http:// consumingantiquity.blogspot.com/

$\mathrm{CSCH}$ 2021. Critical Studies in Cultural Heritage. Accessed 31 May

2021. https://pasithee.library.upatras.gr/csch

Dakouri-Hild A. 2017. Public Archaeologies of the Ancient Mediterranean. Journal of Eastern Mediterranean Archaeology and Heritage Studies 5(3-4): 251-270.

Dassiou O. N., (ed.) 2005. Archaeology and Society: Archaeology through the Eyes of Adolescent Students (in Greek). Thessaloniki: Adelphoi Kuriakide.

DiAZOMA 2021. Accessed 31 May 2021. https://www.diazoma.gr/

Dictionary of standard modern Greek 2021. To xoıvó. Accessed 31 May 2021. https://www.greek-

language.gr/greekLang/modern_greek/tools/lexica/search.html?lq= $\% \mathrm{CE} \% \mathrm{BA} \% \mathrm{CE} \%$ $\mathrm{BF} \% \mathrm{CE} \% \mathrm{~B} 9 \% \mathrm{CE} \% \mathrm{BD} \% \mathrm{CF} \% 8 \mathrm{C} \& \sin =$ all 
Doumas C. 1997. Management Considerations at a Mediterranean Site: Akrotiri, Thera, in: De LA Torre M. (ed.), The Conservation of Archaeological Sites in the Mediterranean Region: An International Conference Organized by the Getty Conservation Institute and the J. Paul Getty Museum, 6-12 May 1995, The J. Paul Getty Trust: 27- 40.

Dragouni M., Lekakis S., SAKellariadi A. \& Touloupa S. 2021. DOI : https://doi.org/10.26220/csch.3617

EEC 2021. Environmental Education Centres. Accessed 31 May 2021. https://kpe.inedivim.gr/

ESDIAPOK 2021. Association of Heritage Management Consultants. Accessed 31 May 2021. http://esdiapok.blogspot.com/

Fotiadis, M. 2001. Imagining Macedonia in Prehistory, ca. 1900-1930. Journal of Mediterranean Archaeology 14.2: 115-135.

Fotiadis, M. 1995. Modernity and the Past-Still-Present: Politics of Time in the Birth of Regional Archaeological Projects in Greece. American Journal of Archaeology 99 (1): 59-78.

Fotiadis, M. 1993. Regions of the Imagination: Archaeologists, Local People, and the Archaeological Record in Fieldwork, Greece. Journal of European Archaeology 1 (2): 151-70.

Galanidou N. 2012. Prologue in the series "Public Archaeology", in: Galanidou N. \& Dommasnes L.H.(eds), Telling Children about the Past: An Interdisciplinary Perspective (in Greek). Athens: Ekdoseis Kaleidoskopio: 7-16.

GAZI A. 2006. "Eh, let them open up a dictionary!" or "Finally, captions we understand!"? Approaching museologically drafting captions for the re-exhibition of the Archaeological Museum of Thessaloniki. Archaeological Work in Macedonia and Thrace 20, Thessaloniki: 381-390.

GAZI A. 1993. Archaeological Museums in Greece (1829-1909): The Display of Archaeology. Unpublished PhD thesis, University of Leicester.

Gogos K. 2004. Immediate Contact of Citizens with Archaeological Sites and Monuments: Access and Use (in Greek), in: Trova E. (ed.), Cultural Heritage and Law. Conference Proceedings, June $3^{\text {rd }}-4^{\text {th }}$ 2003, Athens. Thessaloniki: Ekdoseis Sakkoulas: 297-318.

Gratsia I. \& LEKAKIS S. (eds.) 2010. Monuments of Naxos at Risk. Citizens Talk about Them (in Greek). Athens: Monumenta.

GratZIOU O. 1985. 'Masterpieces Speak for Themselves!' The Survival of an OldFashioned View that Opposes the Educational Policy of Museums (in Greek). Archaiologia kai Technes 16: 37-40.

Grima R. 2016. But Isn’t All Archaeology ‘Public’ Archaeology? Public Archaeology 15(1): $50-58$.

Hamilakis Y. \& Anagnostopoulos A. 2009. Archaeological Ethnographies. Public Archaeology 8 (2-3):65 - 87

Hamilakis Y. 2007. The Nation and its Ruins: Antiquity, Archaeology, and National Imagination in Greece. Oxford: Oxford University Press.

Hamilakis Y. \& Yalouri E. 1996. Antiquities as Symbolic Capital in Modern Greek Society. Antiquity 70: 117-29.

HeLlENiC SOCIETY 2021. Society for the Environment and Cultural Heritage. Accessed 31 May 2021. http://www.ellinikietairia.gr/ 
Herzfeld M. 1991. A Place in History: Social and Monumental Time in a Cretan Town. Princeton, N.J.: Princeton University Press.

HoOper-Greenhill E. 1999. Museum Learners as Active Postmodernists: Contextualising Constructivism, in: HoOPER-GreENHILL E. (ed.), The Educational Role of the Museum, $2^{\text {nd }}$ edition, London and New York: Routledge: 67-72.

Hourmouziadou A. \& Touloumis K. 2010. 'Between Mud and Poetry': Archaeology in the Local Market, in: Stroulia A. \& SutTon S.B. (eds), Archaeology in Situ: Sites, Archaeology, and Communities in Greece. Lanham, MD: Lexington Books: 301-330.

Howery C. 2013. The Effects of the Economic Crisis on Archaeology in Greece. Journal of Eastern Mediterranean Archaeology and Heritage Studies 1 (3): 228-233.

ISTORIMA 2021. Accessed 31 May 2021. https://www.istorima.org/

Kadja K., Marx A., Wright H., Richards J., Marciniak A., Salas Rossenbach K.S., Pawleta M., Van Den Dries M.H., Boom K., Guermandi M.P., Criado-Boado F., Barreiro D., Synnetvedt A., Kotsakis K., Kasvikis K., Theodoroudi E., LÜth F., Issa M. \& Frase I. 2017. Archaeology, Heritage and Social Value: Public Perspectives on European Archaeology. European Journal of Archaeology 21(1): 96-117. https://doi.org/10.1017/eaa.2017.19

Kalpaxis T. 1993. Archaeology and Politics II. The Excavation of the Temple of Artemis (Corfu 1911) (in Greek). Rethymno: Panepistimiakes Ekdoseis Kritis.

Kalpaxis T. 1990. Archaeology and Politics I, Samian Archaeologies 1850-1914 (in Greek). Rethymno: Panepistimiakes Ekdosis Kritis.

KAsviKIS K. 2004. Archaeological Narratives and Education: Content and Pictures" Analysis in School Books in Primary Education (in Greek). Unpublished PhD Thesis, Aristotle University of Thessaloniki.

KOKKINIDOU D. 2005. Past and Power: Aspects of Archaeology in Greek Society and Education (in Greek). Thessaloniki: Vanias.

KotSAKIS K. 2019. The Voyage, in: KOTSAKIS K. (ed.) The Opposite Bank. Social Space and Ideology in Prehistoric Communities. Studies Dedicated to the Memory of Professor G.Ch.Chourmouriadis, Thessaloniki: Aristotle University of Thessaloniki: 13-26.

KoTSAKIS K. 1998. The Past is Ours: Images of Greek Macedonia, in: MesKeLL L. (ed.), Archaeology Under Fire: Nationalism, Politics and Heritage in the Eastern Mediterranean and Middle East. London-New York: Routledge: 44-67.

KotSAKIS K. 1991. The Powerful Past: Theoretical Trends in Greek Archaeology, in: Hodder I. (ed.) Archaeological Theory in Europe: The Last Three Decades. London: Routledge: 65-90.

KotSAKis K., VoKotopoulos L., LeKKa A., and Fourligka E. 1993. Cultural Heritage and Local Community: The Excavation of Toumba in Thessaloniki (in Greek). Paper Presented at the Conference, Monument and Society, organised by the Technical Chamber of Greece, 1 December 1993, Athens.

Kyriakidis E. \& ANAgnostopoulos A. 2017. Engaging Local Communities in Heritage Decision-Making: The Case of Gonies, Crete, Greece. Journal of Eastern Mediterranean Archaeology and Heritage Studies 5 (3-4): 334-348.

LEKAKIS S. \& PANTZOU N. (eds), 2020. Introduction to the management of cultural heritage. $A$ critical review of the field in Greece (in Greek). Athens: Asine publications.

Mcgimsey C. R. 1972. Public Archaeology. New York and London: Seminar Press. 
Matsuda A. 2016. A Consideration of Public Archaeology Theories. Public Archaeology 15(1): 40-49.

Matsuda A. \& OKamura K. 2011. Introduction: New Perspectives in Global Public Archaeology, in: Okamura K. \& Matsuda A. (eds), New Perspectives in Global Public Archaeology, New York, Dordrecht, Heidelberg, London: Springer: 1-18.

Monumenta 2021. Accessed 31 May 2021. https://www.monumenta.org/

Moshenska G. 2017. Introduction: Public Archaeology as Practice and Scholarship Where Archaeology Meets the World, in: Moshenska G. (ed.), Key Concepts in Public Archaeology, London: UCL Press: 1 -13.

Mouliou M. 1997. The "Writing" of Classical Archaeology in Post-War Greece (1950 to the Present): The Case of Museum Exhibitions and Museum Narratives. Unpublished PhD Thesis, University of Leicester.

Moussouri Th. 1999. Research and Evaluation of the Museum Public (in Greek with English abstract). Archaeology and the Arts 72: 56-61.

NixON L. 2001. Seeing Voices and Changing Relationships: Film, Archaeological Reporting, and the Landscape of People in Sphakia. American Journal of Archaeology 105 (1): 77-97.

Oral History Group 2021. Accessed 31 May 2021. http:/ / oralhistorygroups.gr/

PApapetropoulos D. A. 2006. Law 3028/2002 on the Protection of Antiquities and in General of Cultural Heritage. Text-Comments-Interpretation (in Greek). Athens, Thessaloniki: Ekdoseis Sakkoulas.

Petrakos V.C. (ed.) 1995. Christos Karouzos: Short Texts (in Greek). Athens: En Athinais Archaiologiki Etaireia.

Petrakos V. C. 1982. Essay on the Archaeological Legislation (in Greek). Athens: Ministry of Culture and Sciences.

Plantzos D. 2018. Crisis, austerity measures and beyond: archaeology in Greece since the global financial crisis. Archaeological Reports 64. DOI: https://doi.org/10.1017/S0570608418000261

Plantzos D. 2016. The Recent Future (in Greek). Athens: Publications Nefeli.

Plantzos D. 2008. Archaeology and Hellenic Identity, 1896 - 2004: the frustrated vision, in: Damaskos D. \& Plantzos D. (eds.), A Singular Antiquity. Archaeology and Hellenic Identity in Twentieth-Century Greece. Athens: Mouseio Benaki: 11-30.

Poulios I. \& Touloupa S. 2018. Museums and Crisis: The Imperative to Achieve Strategic Agility in the Current Instability. A Case Study of the Major Archaeological Museums in Greece. Public Archaeology 17(1): 3-35. DOI: https://doi.org/10.1080/14655187.2018.1553127

Psychogios N. 2009. Meeting History. Accessed 31 May 2021. http://kavrochorieng.blogspot.com/

SAKALI O. 2017. Museums and Public: Redefining Museum Learning Experience (in Greek), in: Papadimitriou N. \& Anagnostopoulos A. (eds), The Past in the Present. Memory, History and Antiquity in Modern Greece. Athens: Kastanioti Publications: 263-277.

SAKALI O. 2015. Museum Education Discourse in Documentation of Archaeological Educational Programmes: National and Gender Narratives (in Greek). Tetradia Mouseiologias 10: 29-35. 
SAKALI O. \& TSiTOURI A. 2017. Monuments “in the light". Thoughts on Educational Use of Cultural Heritage in Greece (in Greek). Cultural Internationalism and Greek Cultural Policy in the 21st Century. Conference Proceedings Dedicated to the 50 years from the foundation of ICOMOS. ICOMOS - Hellenic National Committee: Athens, 87-100.

Sakellariadi A. 2011. Archaeology for the People? Greek Archaeology and its Public: An Analysis of the Socio-Political and Economic Role of Archaeology in Greece. Unpublished $\mathrm{PhD}$ Thesis. University College London. Available online: http://hdl.handle.net/10442/hedi/35120

Sakellariadi A. 2008. Public Challenges and the Private Ways of State Archaeology: The Case of Greece. Conservation and Management of Archaeological Sites 10 (4): 320-9. DOI: http://dx.doi.org/10.1179/135050308X12513845914426

SAKEllariadi A. 2007. Antiquity, Archaeology and National Identity in 20th Century Greece: Review of a Conference. Public Archaeology 6(3): 188-192.

DOI: http://dx.doi.org/10.1179/175355307X202929

SAKKA N. 2002. Archaeological Activities in Greece (1928-1940). Political and Ideological Dimensions. Unpublished $\mathrm{PhD}$ thesis, University of Crete.

Schadla-Hall T. 1999. Editorial: Public Archaeology. European Journal of Archaeology 2 (2): $147-58$.

SEA 2017. First Call for the Action Day for the Promotion of the Work of the $\begin{array}{lllll}\text { Archaeological } & \text { Service. } & \text { Accessed } & 31 & \text { May }\end{array}$ https://www.sea.org.gr/details.php?id=713

SEA 2013. Second Call "20th -21st October: Day Dedicated to the Promotion of the Multifaceted Work of the Archaeological Service (10/10/2013). Accessed 31 May 2021 https://www.sea.org.gr/details.php?id=23

SEA 2012a. Press Conference of the Association of Greek Archaeologists on the launching of the International Appeal Support Greek Cultural Heritage against IMF Cuts. Accessed 31

https://www.facebook.com/AssociationOfGreekArchaeologistsAgainstImfCuts

SEA 2012b Invitation to Action. 20th -21st October: Day Dedicated to the Promotion of the Multifaceted Work of the Archaeological Service. Accessed 31 May 2021 https:/ / www.sea.org.gr/details.php?id=24

SEKA 2021. Association of Temporarily Employed Archaeologists. Accessed 31 May 2021. http://www.seka.net.gr/s/o-sullogos-mas/anakoinoseis/421-1o- $x \dot{\alpha} \lambda \varepsilon \sigma \mu \alpha-\varepsilon \sigma \varepsilon \alpha$

SHANKS M. 1995. Classical Archaeology of Greece: Experiences of the Discipline. London: Routledge.

SkALTSA M. 2014. Museums and Museology in Contemporary Society. New Challenges, New Relationships (part A') (in Greek). Archaeologia ke Technes. Accessed 31May 2021

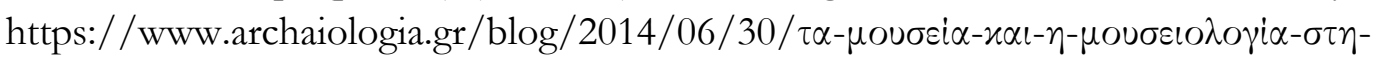

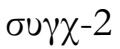

Skoures P. \& Trova E. (eds.) 2003. Protection of Antiquities and of Cultural Heritage. The Law 3028/ 2002 (in Greek). Athens; Thessaloniki: Ekdoseis Sakkoulas.

SNODGRASS, A.M. 1987. An Archaeology of Greece. The Present State and Future Scope of a Discipline. Berkeley: University of California Press.

SOPHRONIDOU M. 2003. Archaeological News in the Newspapers (in Greek). Unpublished $\mathrm{PhD}$ Thesis, Aristotle University of Thessaloniki. 
Stefanopoulou E. 2019. Archaeology and Residential Activism: Reclaiming Philopappou Hill and Plato's Academy, Athens. Unpublished PhD thesis: University of Southampton.

Sutton S.B. \& Stroulia A. 2010. Archaeological Sites and the Chasm Between Past and Present, in: Stroulia A. \& SutTon S.B. (eds.), Archaeology in Situ. Sites, Archaeology, and Communities in Greece. Lanham, Boulder, New York, Toronto, Plymouth, UK: Lexington Books: 3-50.

SutTon D. 1998. Memories Cast in Stone. The Relevance of the Past in Everyday Life. Oxford, New York: Berg.

Theochari E., Kousouri D., Beleri L., Bounia A., Dasiouthis V. \& Partsinevelou A. 2015. Facebook as a Communication Tool of Greek Archaeological Museums, Archaiologia Online. 9th March 2015. Available at:

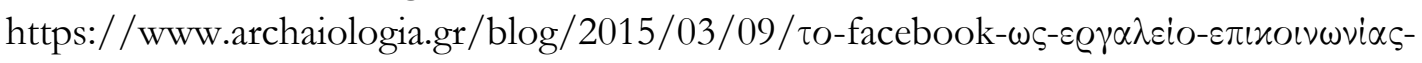
$\tau \omega \nu-\varepsilon \lambda \lambda \eta /$

TheOCHARIS D. 1984. Special Collections or Museums of Special Directions (in Greek), in: Association of Greek Archaeologists (ed.), First Conference Proceedings, Athens 30 March3 April 1967. Athens: Association of Greek Archaeologists: 80-85.

Thermou M. 2010a. The Parthenon: 'The Grandiose Heating Stove of Greece'. Exaggerated Reactions for the new Foreign 'Insult' to the Most Important Monument of Antiquity (in Greek). To Vima, 2 March.

Thermou M. 2010b. Museums...Hostile to the Visitors (in Greek). To Vima, 25 November.

Trova E. (ed.), 2004. Cultural Heritage and Law. Conference Proceedings, June $3^{\text {rd }}-4 \mathrm{t}^{\mathrm{h}} 2003$ (in Greek). Athens; Thessaloniki: Ekdoseis Sakkoulas.

VAROUHAKIS V. (2015). L'Archéologie Enragée. Archaeology and National Identity in the Cretan State (1898-1913). Unpublished PhD thesis. University of Southampton, UK. VOudouri D. 2003. State and Museums: The Constitutional Framework of the Archaeological Museums (in Greek). Athens; Thessaloniki: Ekdoseis Sakkoulas.

Wedde M. 1995. Men across the Ages: 'Open House' at the Minoan Palace of Petras, Siteia (in Greek). Archaiologia kai Technes 55: 70-75.

YALOURI E., 2001. The Acropolis. Global Fame, Local Claim. London, New York: Berg. Zoes A. 1990. Archaeology in Greece. Realities and Perspectives (in Greek). Athens: Polytypo. 